\title{
The Meaning of Baris Kraras Dance Performance at Mengwi, Badung, Bali in the Global Era
}

\author{
Ni Made Ruastiti \\ Lecture of Faculty of Performing Arts \\ Indonesia Institute of the Arts Denpasar \\ Bali-Indonesia
}

\begin{abstract}
This article was compiled from the research results that aimed to understand the meaning of BarisKraras Dance performance at Mengwi, Badung, Bali in the global era. This research was conducted due to the imbalance between the assumption and the reality in real life. Generally, advanced and modern society will be more interested with and enthusiastic to maintain the form of performances in which the choreography is beautiful and easy, and the performance is affordable. However, the reality is different. The questions are: how is the form of the BarisKraras dance performance?; what is the meaning contained inside the performance in this global era?. This research applied qualitative method. The sources of the research data were the BarisKraras dance performance, the related informants including the dancers, stakeholders, religious leaders, custom leaders, elders of Mengwi Palace, local people, and journals of similar research results that have been produced by previous researchers. All data, which had been collected by observation techniques, interviews, and literature studies, were then analyzed by using aesthetic theory, religious theory, and the theory of power relations.The results showed that: The society of Mengwi, Badung performed the BarisKraras Dance in the conventional form without story. It could be seen from the way of presentation, choreography, performance structure, dressing, makeup and musical accompaniment of the performance. Currently, people of Mengwi, Badung, Bali still preserve BarisKraras Dance because they consider that the dance has religious, social and cultural meanings. The belief of the local society in myths about the essence of life that underlies the ceremonial dance was so strong so that until now they still preserve BarisKraras Dance.
\end{abstract}

Keywords: Meaning, BarisKraras Dance Performance, Ritual Ceremony of AciTulakTunggul, Taman Ayun Temple, Mengwi, Badung.

\section{Introduction}

In Bali, there are many Baris Dances for ceremony (Ismadi et.al., 2013). It is because each of the major temples of Bali has its own distinctive ceremonial Baris Dance whose name is often associated with the weapons or property carried by the dancers. The word 'Baris' was defined by many experts and artists such as Walter Spies and Beryl de Zoete (1938) as the line or composition of soldiers. A similar opinion was also expressed by Miguel Covarubias (1972) that the word 'Baris' could mean lined or military troops lining up. In, Bali there are 30 types of Baris Dance, consisting of Baris Tumbak Dance, Baris Poleng Dance, Baris Ketekok Dance, Jago, Baris Kraras Dance, Baris Pendet Dance, Baris ChineseDance, Baris Gede Dance, Baris Bajra Dance, Baris Presi Dance, Baris Omang Dance, Baris Jojor Dance, Baris Tamiang Dance, Baris Goak Dance, Baris Nuri Dance, Baris Irengan Dance, Baris Derma Dance, Baris Lutung Dance, Baris Kelempe Dance, Baris Cendekan Dance, Baris Panah Dance, Baris Jangkang Dance, Baris Gayung Dance, Baris Taruna Dance, Baris Juntal Dance, Baris Cekuntil Dance, Baris Bedil Dance, Baris Butterfly Dance, Baris Cerekuak Dance, Baris Topeng Dance, dan Baris Demang Dance. Each Baris Dance has unique and distinctive characteristics. However, Baris Dance is generally performed by four to sixty four male dancers. Unlike the case ofBaris Kraras Dance which is performed in the ritual ceremony of Aci Tulak Tunggul at Mengwi Village, Badung which is only performed by a dancer. The Baris dancers generally use beautiful make up and clothing made of cloth covered with gold prada. On the other hand,the dancer of Baris Kraras Dance only uses a cloth made of kraras (dried banana leaf) with a headdress made of pork. 
Taman Ayun Temple is a sungsungan temple of the people of Mengwi Village that is led by the leaders of Mengwi Palace. The social bonds that existed since the ancient times, when Mengwi Kingdom struggled together with its people (the people of Mengwi Village), is still reflected from the loyalty of the people to take care of Taman Ayun Temple. Such social bond is manifested by the local people in the form of joint prayer activities at the peak of the piodalan ceremony at Taman Ayun Temple. Up to now, the people of Mengwi Village are still loyal to do "ngayah" at Mengwi Palace if there is a ceremony held in the puri; either the ceremony relates to ceremony at Taman Ayun Temple or the ceremony of manusayadnya including: teeth-cutting ceremony, marriage ceremony, ceremony of death (ngaben) and so on in the puri. Similarly it happens vice versa; if one of the peopleconducts a similar ceremony, then the palace also come to attend and give donations to its people. All of theseare done voluntarily and based on the value of mutual cooperation. The existence of social link between Mengwi Palace and the surrounding villages gives a positive impact for the maintenance of some Mengwi Village assets such as the existence of Taman Ayun Temple which is still sustainable up to now.

The beautiful and beautiful Taman Ayun Temple is surrounded by a lake that is usually used by local people to fish and irrigate the rice fields. Spatial architecture of Taman Ayun Temple is divided into three parts so-called tri mandala. Tri mandala consists of main mandala or jeroan, madya mandala or middle jaba, and nista mandala or side jaba. In the main area of the mandala or jeroan of Taman Ayun Temple, there are several sacred buildings namely pelinggih or penyawangan of the temples throughout Bali including Batur Temple, UlunSuwi Temple, and so on. In the area of madya mandala (middle jaba), there is apenyawangan of DalemBekak Temple. In addition, in the area of nistamandala(side jaba) there are wantilan, PelinggihSiluhResi and LuhurPurnama Temple (with 6 buildings or sacred pelinggih). To the northeast of the offshore area of Taman Ayun Temple, there are Gedong Sari Bhatara Tengah Segara, sambiangan and pepelik. Meanwhile, outside the Taman Ayun Temple area, there are BatuAyapelinggih and BedugulKramaCarik Banjar Badung. In the Southwest, across the highway, there is a water dam that is usually used as a location for mecaru and does the ritual ceremony of AciTulakTunggul which is always followed with BarisKraras Dance performance.

Baris Kraras Dance is a ceremonial dance that is performed by a male dancer wearing clothes made of kraras leaves (banana leaf) that has been dried and is accompanied by kidung songs. A ceremonial dance is often performed in the context of the ritual ceremony of Aci Tulak Tunggul (ritual ceremony for avoiding bad things) which is held once a year exactly on every Tuesday Kliwon, Wuku Medangsia at Taman Ayun Temple, Mengwi, Badung. Baris Kraras Dance performance is very unique because it is performed in a different concept compared to the way of Baris dance performance of other ceremonies in Bali. Generally, Baris dance,in a ceremony is danced in pairs and ended by a war scene. Unlike the case of Baris Kraras Dance at Mengwi Village, Badung, it is only danced by a dancer. In addition, the end of the performance is not ended by the war scene although they danced with a small weapon of keris made of pork wrapped satay. This article is compiled from the research results that aimed to understand the meaning of Baris Kraras Dance performance at Mengwi Village, Badung, Bali in the global era. Mengwi Village, Badung is located about 16 Kilometers in the Northwest of Denpasar city; on the highway that connects Denpasar and Singaraja. The highway that runs in front of Taman Ayun Temple is a highway that connects Tabanan and Gianyar. The location of Taman Ayun Temple, where the Baris Kraras Dance is performed in the middle of the crossing point of these four cities. The people of Mengwi Village, who are dominantly Hindu, have eleven Banjars:Banjar Batu, Banjar Gambang, Banjar Pande, Banjar Munggu, Banjar Pandean, Banjar Serangan, Banjar Peregae, Banjar Lebah Pangkung, Banjar Pengiasan, Banjar Alangkajeng, and Banjar Delod Bale Agung. Mengwi village is bordered by the villages of Badung Regency and the villages of Tabanan Regency. To the north, this village is bordered by Werdi Bhuwana Village; Gulingan Village to the east; Mengwitani Village to the south; Abian Tuwung Village to the west.

This article was compiled from the research results that aimed to understand the meaning of BarisKraras Dance performances at Mengwi Village, Badung, Bali in the global era. This phenomenon is interesting to research because of the imbalance between the assumption and the reality in the real life. Generally, advanced and modern society will be more interested with and enthusiastic to maintain the form of performances in which the choreography is beautiful and easy, and the performance is affordable. However, the reality is different. Although BarisKraras Dance is performed with a very simple choreography, even away from the word 'beautiful', also makeup and clothing consisting of dried banana leaves and raw pork, but people at Mengwi Village still preserve the dance up to this global era. The questions are: how is the form of the BarisKraras dance performance?; what is the meaning contained inside the performance in this global era?.The disclosure of this phenomenon has both theoretical and practical urgency. 
Theoretically, the results of this research are expected to provide benefits in the development of science, especially in the field of performing arts through an in-depth research of BarisKraras Dance. Practically, the results of this research can be used as information related to the preservation of performing arts, especially in Bali as well as in other areas.

\section{Research Method}

This research applied qualitative method. The primary data source of the research was BarisKraras Dance performance and the related informants that were selected based on the purposive sampling technique. The selected informants included the dancers of BarisKraras Dance, stakeholders, ceremonial leaders, leaders, elders, elders of Mengwi Pallace, village officials, and local people. The addition of informants to supplement the data was conducted by using snowball sampling technique.

This research also used secondary data that was obtained through literature studies by tracing the results of similar research that have been produced by previous researchers. All data, which had been collected by observation techniques, interviews, and literature studies were then analyzed by using aesthetic theory, religious theory and the theory of power relations.

\section{Result and Discussion}

\subsection{The Form of BarisKraras Dance Performance}

The formation of performing arts is inseparable from the adaptation of humans to their environment (Pradana, 2018a; Pradana, 2018b; Ruastiti, 2016).Social and demographic values of a region play a role in influencing the performing arts (Pradana, 2018a; Sunarto et.al., 2014).Ruastiti (2017) argued that the behavior of people that is affected by the ideological superstructure also influences the art form of the society. It is because the superstructures including value system, belief system, and custom are the foundation and thinking pattern of the society in art (Ruastiti, 2011). Ruastiti (2017) stated that social culture, demography and superstructure are artistic ideologies for a society. The formation of the Hindu-style BarisKraras Dance performance at Taman Ayun Temple, Mengwi Temple reflects the situation of environment, religious, social and cultural life of the peopleat Mengwi Village.

According to the stakeholder, the ceremonial leader at Taman Ayun Temple Mengwi once when the dam was built, it always had problems. Below is the dam where the ritual ceremony of AciTulakTunggul carried out.

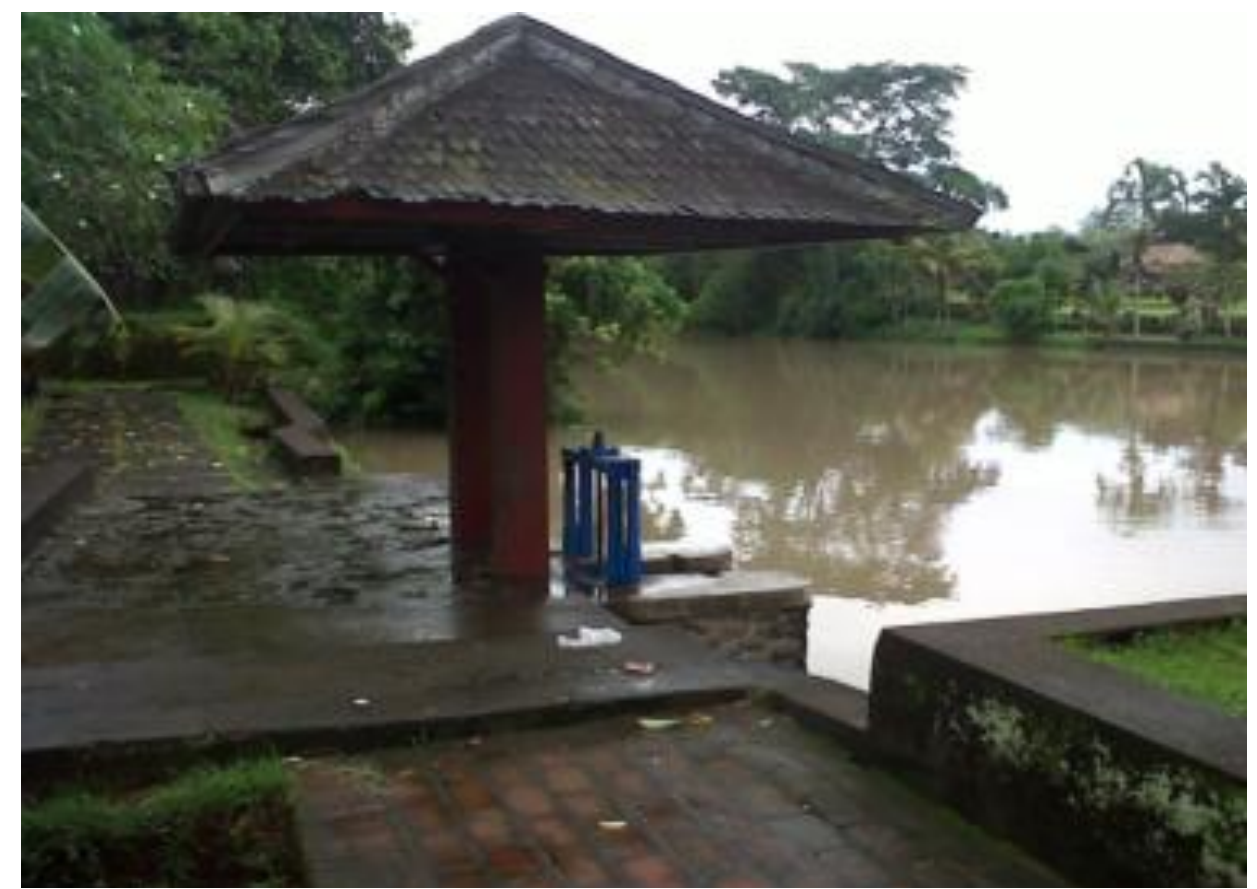

Figure 1: Taman Ayun Temple MengwiDam as The Location of BarisKraras Dance Performance (Doc. Ruastiti, 2017) 
It happened continuously. Finally, the stakeholders got a revelation or guidance for subak people at Mengwi Village to make the ritual ceremony of AciTulakTunggul (ritual ceremony for avoiding bad things) at Taman Ayun Temple dam along with the ritual ceremony of piodalanjelih at Taman Ayun Temple Mengwi.

The ritual ceremony of AciTulakTunggul is a ritual ceremony for avoiding bad things in the form of pakelem (offerings that is swept away to the water) using the medium of bantenpemayasan of BarisKraras in the form of perasdaksina, bantenpengeleb consisting of bantenpakelingasoroh, perasdaksinagedesarwakutus equipped with segehanagung, pengebebselemduck and chicken containing seven rice cones, palabungkah and palagantung (agricultural product), sticky rice, injin, jinahbolong, sepasatus, pengelebselem duck(cattle that is swept away to the water in the form of black duck) and chicken, carusiapselem(offerings of cattle that is buried on the ground), followed by BarisKraras Dance performance.

The offerings of the pakelem (swept away to the water), which isled by pemangku (Hindu ceremonial leader) of KhayanganTiga Temple and pemangku of Taman Ayun Temple are witnessed by Penglingsir ofMengwi Palace. They dedicate all the offerings to the ruler of the dam at Taman Ayun Temple, Mengwi who is believed to affect the lives of the people in the village. Based on the belief of the people, people of Mengwi Village, especially kramasubak(group of rice farmers) in the village, perform the ritual ceremony of AciTulakTunggul in the modernization socities. They hope that by carrying out the rituals there will be no things they do not want to happen and hope that their efforts in farming can produce abundant results.

By the observation to the concept of the show, BarisKraras Dance at Taman Ayun Temple Mengwi, Badung is performed in the primitive form. It can be seen from the choreography, the way of performance, makeup, clothing and the musical accompaniment of the performances. The choreography of BarisKraras Dance performance, that is built from various dance motions of bebarisan dance or traditional Balinese putragagahandance is performed conventionally by carrying the principle of balance between right and left, front and back. BarisKraras Dance is danced by a male dancer wearing a headdress made from a banana stem that is decorated with pork satay.

BarisKraras Dance, which is accompanied by kidungsongs is performed with Hindu symbols. It can be seen from the procession or the way of presentation, makeup and clothing, as well as the weapons brought by the dancers. Before dancing, BarisKraras Dance, which is performed by a male dancer is initially decorated by clothing in the form ofawiran or sesaputan made of kraras (dried banana leaves) using a headdress made of banana leaves containing rebasan, wrapped satay, urutan necklace of pork. As shown in the picture below.

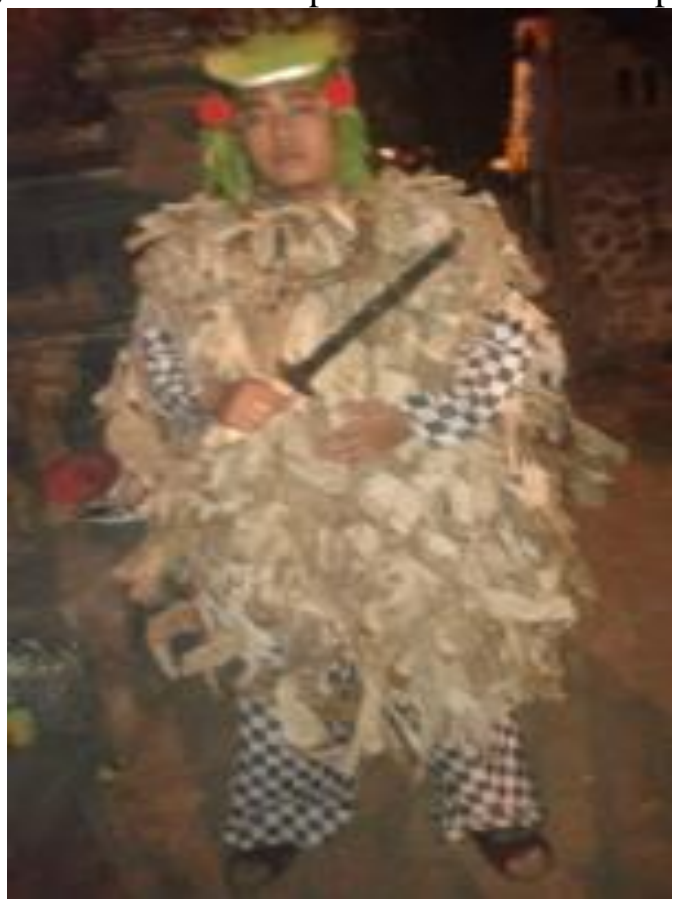

(Doc. Ruastiti, 2017)

Figure 2: Costume of BarisKraras Dance

BarisKraras Dance, which is built from a variety motion of nayog (slow walking motion), agem (basic stance in Balinese dance) is performed with the performance structure: (a) pengawit, is the first part of the show marked by 
the locomotive motion in the form of nayog, slow walking motion; (b) penguncab, is a locomotive motion of nayog in a faster tempo with stronger power and motion quality; (c) pakelem, is when the dancer getting off the clothing used, both kraras leaf and headdress which then swept away to the dam water of Taman Ayun Temple. BarisKraras Dance, with the theme of the heroic dance, uses a small weapon made of pork wrapped satay. At the end of the performance, BarisKraras Dance does not perform a war scene. The dancers only incise their weapons to the offerings of bantencaru as a symbol that the ritual ceremony of AciTulakTunggul stump is valid and completed already. The dancers of BarisKraras Dance then open up all their clothing and headdresses that are also made of pork to be swept away at the dam water of Taman Ayun Temple. Offering scene of the ritual ceremony of AciTulakTunggul looks very solemn because during the performance all subakpeopleof Mengwi Village accompany the performance by kidung songs.

BarisKraras Dance, which is performance by the local people of MengwiVillage has become an important part of the ritual ceremony of AciTulakTunggulat Taman Ayun Temple Mengwi, Badung. Because of its sacred characteristic, BarisKraras Dance cannot be performed outside the context of the ritual ceremony of AciTulakTunggul so that the dance becomes very rare. People who want to watch BarisKraras Dance performance have to wait for the ritual ceremony of AciTulakTunggul at Taman Ayun Temple Mengwi which is held every once a year.

Ritual ceremony of AciTulakTunggul Ceremony is a one-year nature purification ceremony that is carried out massively by the people of Mengwi Village, Badung. The ceremony comes from Sanskrit which has the meaning of harmonious, balanced, and harmonious between human behavior and the natural environment in which they live. To have harmonious and balanced human life on earth, then they purify themselves, purify the natural environment, and bring themselves closer to God the Creator by carrying out the ceremony (Pradana, 2018b; Pradana, 2016; Whitehouse, et.al., 2014). Religious ceremonies carried out yadnya (offerings) as a means of purification of human and nature around them.

Ritual ceremony of AciTulakTunggul is interpreted by the people of Mengwi Village Badung as a big ceremony. In the sense that many offerings are used, the large number of followers of the ceremony, and also a rousing ceremony. Ritual ceremony of AciTulakTunggul is believed by the local people as a celebration for their successful living as farmers. At that time, the subak people of Mengwi Village perform the offering ceremony in the form of agricultural products to the God of Fertility which is believed to be in the embankment of Taman Ayun Temple Mengwi. Ritual ceremony of AciTulakTunggul is held every once a year and followed by pengempon (community supporters) of the temple that used to work as rice farmers. The people's belief that BarisKraras Dance is a form of offering to God 'Ida Sang Hyang WidhiWasa' for the safety, fertility and peace. With such belief, every personal ofMengwi Village does not dare to take actions that deviate from the tradition that has been going on. Violations or deviations in connection with ngayah tradition (carrying out the obligations) as members of the sekaa BarisKraras Dance are believed to have implications for the emergence of problems in their lives.

BarisKraras Dance which is considered as part of the implementation of AciTulakTunggul ritual ceremony is considered as sacred. It attaches to the art and influences the attitude and actions of local people in preparing the ceremony and the formation of art sekaa (group), the determination of good days, the selection of dancers, the provision of sekaakidung as dance music and so on. Although BarisKraras Line is performed every single year, but all its preparations have been done for several months before the performance day. The candidate selection of BarisKraras dancers of person is selected on the terms appointed by the pemangku (religious ceremonial leader) at Taman Ayun Temple. The requirement is often difficult for the people of Mengwi Village to get a prospective dancer. Those who are elected as the prospective dancers of BarisKraras Dance will certainly have implications for the families because the dancers are generally regarded as sacred and special person so that they are not allowed to do haphazard work in public. The demands of life and heterogeneity of the community occupationat Mengwi Village are no longer concentrated in the village but there are many who live in urban areas, which it is a challenge for the dancer of BarisKraras Dance. Community activities of Mengwi Village became very crowded, besides preparing dancers, they also prepare ceremonial equipment.

People of Mengwi Village have the duty to do ngayah (work devotion) in the village. It is carried out because all the banten that are needed in order to perform the ritual ceremony of AciTulakTunggul in Taman Ayun Temple Mengwi done by mutual cooperation. The people who are selected as the dancer of BarisKraras Dance must be willing to sacrifice their time to follow the sacred process of the performance. 
To anticipate the various problems that arise during the preparation to become the dancer of BarisKraras Dance, people also makes a purification ceremony which is directly led by the pemangku (religious leaders) at Taman Ayun Temple Mengwi. The ceremony (ritual) is to avoid disturbance, both the sekala (empirical reality) and the niskala (non-empirical reality) disturbances. By having the ritual,the people expect that the all people involved including the dancer or ritual ceremony executors are safe in carrying out the ceremony.

In addition to preparing the dancers, people of Mengwi Village are also still looking for new kidung player to replace the old player. The regeneration of kidung player also takes time to practice so that at the time of the performance there is a compact synergy between the dancers and the dance accompaniment. Under consideration that BarisKraras Dance at Mengwi Village is a sacred dance that is highly respected by the local people, whatever the implications of the preparation and execution of their performance are voluntarily shared. Social solidarity that grows on everyone who is a society member of Mengwi Village is not born from forced attitude. They assume that the obligation to be implemented is an agreement from every parumandesa (village meeting).

Parumandesa is conducted periodically every month which discusses various problems that occur in the environment of Mengwi Village Badung.The village meeting that is led by BendesaAdat (customary village leader) attended by all kramaadat (customary villagers) by wearing light custom clothing. Every family head (KK) of Mengwi Village who is recorded as a karma adat must be present in parumandesa to listen and give suggestion for the smooth development of the village in physical, mental and spiritual development. Every person has the same voting rights in parumandesa. The contribution of suggestions that is considered as useful for the development of the village will be a pesuaran (trial). Every opinion of the peopleof the village is always taken as consideration and if the majority of the people think that the opinion is good and useful then that individual opinion will then become the material for establishing the awig-awig (customary law of the village) of the customary village. The purpose of parumandesa and the establishment of awig-awigof the customary villageare to solve village problems as early as possible without conflict between the villagers. Rahmawati and Ruastiti (2018) stated that the representations of individual ellesetre presentations collectives (individual ideas which are then recognized by the society as the group's idea).

BarisKraras Dance performance will indirectly have the implications for the economy. Consumption costs for the preparation and purification process of the dancers require considerable funding. The material and financial needs associated with the formation of sekaa (group) of BarisKraras Dance mostly come from local people's donations. People are successful in the field of economics come to do donation because the success achieved is believed to have something to do with the ceremony held at Taman Ayun Temple Mengwi.

Religious ideology remains the guideline of the people in decision making. They believe that the more donation, they will get more and more sustenance. Every individual who is selected to be a dancer initially felt worried about being disturbed by the supernatural forces. By having the purification ceremony, BarisKraras dancer feels protected from the outside negative influences. By having the process of purification they become convinced and resilient to carry out activities as the dancers of BarisKraras Dance.

People of Mengwi Village Badung have a belief that before starting every activity especially those related with custom and religion activity must be starting with melukat or ruwatanfor purification. They consider that the process of ruwatan can neutralize all kinds of obstacles or disturbance either niskala (non-empirical reality) or sekala (empirical reality). It is not only applied to the candidate dancer of BarisKraras Dance but also applied to all the equipment used in the ritual ceremony of AciTulakTunggul in Taman Ayun Temple Mengwi.

To be selected as the dancer of BarisKraras Dance indirectly gives the opportunity to develop self-potential. In addition to obtain mental and spiritual temporal, the dancer also acquires dancing skills. Although, they are only taught to practice BarisKraras Dance but they can develop the basics of the dance. At Mengwi Village, Badung a pragina has its own place in society. If they are invited to dance in a ceremony, a pragina will be specifically invited to use the traditions prevailing in the village. An invitation to a pragina is called an uleman (custom invitation) conducted by a family or an institution that organizes the ceremony. By the day of the performance, all invited dancers are placed in a special room, entertained and served with the utmost respect by the performance organizer. Ideologically, self-actualization in such phenomena encourages each actor to be more confident having performance in public (Pradanaet.al., 2018; Laborde, 2014). 
The dancers who are selected in BarisKraras Dance performance are very pleased with their experiences performing in ritual ceremony of AciTulakTunggulat Taman Temple AyunMengwi. Numerous compliments they gained for their performances as the dancers of BarisKraras Dance is a sweet experience that is unforgetable. It certainly has implications for the achievement of a deep sense of gratitude because the rewards can only be obtained only by certain people.

BarisKraras Dance performance provides an opportunity for the dance artist to actualize himself as a strong and brave warrior who welcomes the God.In relation to BarisKraras Dance performance which has a close relationship with the implementation of ritual ceremony of AciTulakTunggulthen the stakeholders optimally change the attitude and the nature of the dancers become quite strong to approach the nature and the character of a soldier. The formation of the attitude ideologies is concerned for the character formation of the next generation from Mengwi Villager. Through the ceremonial dance, the community is able to maintain the local cultural identity in facing the onslaught of global culture. Ruastiti (2017) stated that character education that is taught early will affect the establishment, decision-making in addressing life in order to not easily be influenced by a variety of negative external cultural influences.

By paying attention to cultural activities that are taught to the dancers, it seems that the process can support the community life in the area. As they performed BarisKraras Dance, the communities directly involved in the ceremony indirectly obtained an informal education on religion, art and history. They become more confident in the ceremony event. Community involvement in the performance made them more skillful in dancing and singing the kidung. Indirectly, they know and understand the cultural heritage of their region.

The arts group that performs the ceremonial dance is always supported by all people of Mengwi Village because it is in accordance with local tradition that reflects the tolerance and togetherness. It also gives their own prestige which spurred the interest of the people to preserve their local culture through BarisKraras Dance either actively or passively. BarisKraras dancer who has danced the ceremony is indirectly got the benefit in the continuation of local cultural values. The existence of BarisKraras Dance indirectly has the implications for the preservation of local culture. BarisKraras Dance in that context is considered very important for the local people because the elemental culture contained in the dance is considered relevant to maintain their social unity across generations. BarisKraras Dance has been continuously hereditary becoming witnesses as well as evidence of their solid presence in an artistic taste.

\subsection{The Meaning of BarisKraras Dance Performance}

Meaning is part of semantics and speech (Ruastiti, 2010). Meanings can be interpreted in various ways. It is always integral to the sentence and speech of its people collectively. It means that the meaning is a part of life that is made up of the experience, tradition, history and relations of its social relations. The meaning is socially intangible that gives more value to the actions of the people. As the people of Mengwi Village in interpreting BarisKraras Dance as part of the tradition of AciTulakTunggul ceremony at Taman Ayun Temple, it has mediated the talents of society art collectively. Deconstructively, dance performances are an aesthetic practice mobilized by the collective beliefs of the local people (Ruastiti, 2017; Ruastiti, 2011). BarisKraras Dance still preserve by the people of Mengwi Village up to now because it as a ceremonial dance of AciTulakTunggul. Through a series of ceremonies involving power relations, they rearrange their social structure for the benefit of the collective purpose. The construction process has an impact on the formation of a collective positive image of the people arMengwi Village for the enforcement of harmony and social control in the village. Religious activity can foster the respect and discipline of the people in creating harmony for a sense of unity(Pradana, 2018b; Heywood et.al, 2014; Jackson, 2014).

BarisKraras Dance performance contains aesthetic meaning. The aesthetics performance of BarisKraras Dance can be understood through the symbols that are expressed by the players either through the range of motion, the dressing and makeup, or the properties. The aesthetic meaning of a performance will be realized if the motion and its accompaniment are balanced and proportional (Ruastiti, 2011; Ruastiti, 2017; Ruastiti, 2010). The aesthetic meaning of BarisKraras Dance performance can also be seen from the dominance of the brownish dressing and makeup. Brown color contains natural meaning(Adams, 2016; Silva, 2017). The aesthetic meaning of BarisKraras Dance performance can also be seen from the clothing;it is awiran or sesaputan made of kraras leaves or dried banana leaves. It can also be seen from the headdress worn by the dancers; it is a stem of banana in temple-shaped form containing pork satay. Everything was arranged to resemble a bend like the headdress of BarisKraras Dance in general. 
BarisKraras Dance performance include the balance value, the harmony that is expressed through the range of motion, and the floor pattern that is presented in a balanced composition between right and left. Harmonization between motion and kidung songs as the musical accompaniment of the dance can create a peaceful atmosphere (Ruastiti, 2016; Heywood et.al., 2014). Meanwhile, the beauty of the dance that is filled with religious symbols can be interpreted as a sacred truth (Pradana, 2017a; Ruastiti, 2016; Heywood et.al., 2014). BarisKraras Dance performance, which contains nayog motion; walking slowly, can be interpreted as a form of majesty and the sanctity of the sacred offerings to God the creator of the universe.

BarisKraras Dance performance at Taman Ayun Temple, Mengwi contains religious meaning. By observing BarisKraras dance performance that uses awiran or sesaputan from kraras leaves; old banana leaves and headdress from the banana stem, it can be understood that BarisKraras Dance is full of religious meaning. Especially, when it is observed from the variety of motion and musical accompaniment of the performances which is in the form of kidung songs, it is full with religious nuances of Hinduism. According to the custom elders of the village, they said that BarisKraras Dance performance is performed by an adult male dancer that means a symbol andan interpretation of the form of the dam ruler, Bhuta Kala who is being offered the offerings includingbantenpakelem and caru.BarisKraras Dance performance is interpreted as a form of bhuta kala using a headdress in temple-shaped and triangle-shapedform which looks like the headdress of Baris Tunggal dance which contains rebasan, wrapped satay, necklace from pork and weapon in the form of satay. Meanwhile, the kraras leaf is interpreted as a dirty and creepy shape of Butha Kala. BarisKrarasdanceperforming the aesthetic elements of religious nuance is performed harmoniously between the range of motion and the musical accompaniment of the performance. The aesthetics of Hinduism inBarisKraras Dance performance is expressed so harmoniously with the music of its accompaniment. The aesthetics meaning of BarisKraras Dance has a distinctive Balinese cultural identity.

People of Mengwi Village, Badung place KhayanganTiga Temple as the state of power or the central to religious power. Natural environment as palemahan (region) for Mengwi villagers, Badung is believed to have supernatural powers to free themselves from the anxiety in their lives. On the other hand, by performingBarisKraras Dance they believe that their relationships with the natural environment will be harmonious. Nature is believed to have power in giving grace and disaster. Grace and disaster in the world is believed to be inseparable from the laws of nature. The laws of nature work in regulating the cycle of the universe. Each phase of the natural cycle is believed to be determined by Ida Sang HyangWidhi's power. The natural energy controlled by the Gods is believed to have the effect of supernatural powers for the salvation and fortune of human life. The miracle of the natural energy makes the mankind feel amazed. The similar thing happens to the people of Mengwi Village, Badung who worshipsHis presence through the ceremonial symbols that accompanied the performance of BarisKraras Dance up to now. The religious practice continues peacefully because it has been interpreted as sacred since the time of their ancestors in which could not be separated from supernatural powers. BarisKraras Dance performance at Taman Ayun Temple Mengwi, Badung has been able to increase people's understanding of Ida Sang HyangWidhi's existence. The religious practice is believed by the local people as a source of happiness and supernatural powers. God is believed to have a high value associated with the essence of life (Rahmawati and Ruastiti, 2018).BarisKraras Dance performance that is performed regularly and continuously is believed to bring happiness and inner comfort to the peopleofMengwi Village. It means that supernatural powers can be achieved through religious devotion. In religious view, the moment of the ceremony for the local people plays a role to reintensify the dependence between humans and Ida Sang HyangWidhi. In that context, every person in Mengwi Village can maintain the solidity of their kinship through BarisKraras Dance performance at Taman Ayun Temple. The life essence of traditional community is obedient to their belief (Pradana et. al., 2016; Whitehouse et. al, 2014). Theoretically, ritual is a very difficult expression of religious faith among the society (Heywood et.al., 2014; Pradana, et. al., 2016). The religious meaning of BarisKraras Dance performance is imprinted strongly to the people so that BarisKraras Dance is still alive in the passion of the people until global era. It is reflected in the expression of the parties who are always serious and full of joy to continue the cultural tradition. The strength of religious meaning is reflected in the expression and attitude of the people in continuing their tradition (Pradana, 2018b; Sunartoet.al., 2014; Whitehouse, et al., 2014).

BarisKraras Dance performance at Taman Ayun Temple Mengwi can be in social meaning. It can be seen from the activities of the people in carrying out the ritual ceremony of AciTulakTunggul which is always equipped with the performance of BarisKraras Dance at the dam of Taman Ayun Temple. 
The local people always hold the aspect of togetherness. They feel that it is lighter and easier to perform the ceremony by doing it together. All the religious mechanisms underlying the ceremony are carried out in a mutual way. They work hand in hand from the preparation to execution of the ritual ceremony in order to maintain the balance of the natural environment. The empowerment of the society that has been incarnated in the people's interest to perform BarisKraras Dance seriously has an impact on the appearance of the order and the beauty of the ceremony. It shows the religious social spirit that underlies the performance BarisKraras Dance. The meaning of social solidarity seems very strong in performing BarisKraras Dance. It can be seen from the involvement of inter-citizen relations in maintaining harmony in togetherness. It is necessary to solve their increasingly complex life problems. Therefore, people often use the performing arts as a medium of strengthening the bond of social relations (Pradana, et.al., 2018; Waweru, 2015). The meaning of solidarity means that all citizens cooperatively support each other in dedicating BarisKraras Dance performance. It is carried out by all people of Mengwi Village; it is having voluntary social activities so-called ngayah to prepare everything related to the ceremony. Ngayah activities are still relevant in fostering the integration, communication, and unification of understanding in lightening the collective burden and village security. Through the arts, the people can preserve their traditions and culture (Pradana, 2017a; Ruastiti, 2011; Ruastiti, 2016).

The performance of BarisKraras Dance can mean culture. It means that the people of Mengwi Village, who always carry out the ritual ceremony of AciTulakTunggul that are equipped with BarisKraras Dance performance at the dam of Taman Ayun Temple Mengwi do not directly have implications for the preservation of culture. Culture can be preserved through the process of internalization, socialization and enculturation (Pradana, 2018; Waweru, 2015; Ruastiti, 2016; Ruastiti, 2017). People of Mengwi Village continue the cultural values through BarisKraras Dance performance. Their togetherness in continuing the values of adiluhung contains in BarisKraras Dance performance is an important elemental culture that can give their identity, characteristic and sense of pride as Mengwi villagers. They assume that the most relevant act of art is carried out to preserve the social unity in their society. The people who are selected as the dancers BarisKraras Dance or are involved in ceremonial rituals are proud of being rated as special people. The dancers of BarisKraras Dance feel to be a preferred citizen because they are appointed as a container or seat of Bhuta Kala as the ruler of the dam at Taman Ayun Temple. One would be proud if given the opportunity to present his/her abilities in front of the audience (Ruastiti, 2016; Ruastiti, 2011).

The continuation of cultural values through BarisKraras Dance performance is not only performed by the local residents but also performed by the dancers as the performers. Various cultural components contained in BarisKraras Dance performance is indirectly sustainable due to the continuous efforts that are done by the people. Cultural traditions that are deemed to have a worthy value will always be used by the community to organize their lives (Suryawati et.al, 2018; Rahmawati and Ruastiti, 2018).

By paying attention to the cultural activities taught to the dancers, it seems that during the process, they received ethical education in the form of courtesy in their society. It is very supportive to the cultured life at Mengwi Village. Every element of culture has a certain meaning that is very influential for the values and norms to the related society. When they are involved in BarisKraras Line performance, especially the dancers indirectly obtain an informal education about religion, art and culture. The continuity of BarisKraras Dance performance that is performed in the context of ritual ceremony of AciTulakTunggul at Taman Ayun Temple is indirectly a strategy of forwarding cultural values. Through the performance, a noble cultural tradition will always be used by the community in organizing their lives (Ruastiti, 2011; Whitehouse et. al, 2014; Ruastiti, 2016; Kumar, 2013). The point of view of the peopleatMengwi Village against BarisKraras Dance performance is considered very beneficial for the fulfillment of their comfort life. By maintaining BarisKraras Dance performance, all people have participated in continuing local cultural values sustainably to the next generation. Cultural values are the giver of the community's identity (Pradana, et. al.,2017b; Ismadi et.al., 2013).Thus, the performance of BarisKrarasDancethat is performed by the local peopleis very meaningful in the cultural enculturation at Mengwi Village.

\section{Conclusions}

Based on the above description, it can be concluded that BarisKraras Dance is a ceremonial dance that is performed in the primitive form without story. It can be seen from the way of presentation, choreography, structure, dressing and makeup and musical accompaniment of the performance. 
Choreography of BarisKraras Dance performance is constructed from a variety of traditional Balinese Baris dance or male dance that is performed conventionally. BarisKraras Dance is danced by a male dancer using the dress of awiran or sesaputan made of kraras leaves; dried banana leaves and a headdress made from banana stem leaves containing rebasan, wrapped satay and necklace made of pork. BarisKraras Dance accompanied by kidung songs is performed with the following performance structure: (a) pengawit; (b) penguncab; (c) pakelem, the dancer takes off the clothes that are worn then sweep it away in the empelanwater of Taman Ayun Temple.

People of Mengwi Village, Badung, Bali still preserveBarisKraras Dance performance up to now because the dance is considered to have religious, social and cultural meanings for the local people. The local people's believes in the myths about the essence of life that underlies the ceremonial dance is so strong so that they still preserve BarisKraras Dance performance until global era.

\section{References}

Adams, Z. (2016). On the Genealogy of Color. New York: Routledge.

Heywood et.al. (2014). "Meant to be": How Religious Beliefs and Cultural Religiosity Affect the Implicit Bias to think Teleologically'.Religion, Brain \& Behavior 4 (3), pp 183-201.Retrieved from https://doi.org/10.1080/2153599X.2013.782888 : E-Journal [17/5/2013].

Ismadi, H.D. et.al. (2013). 'Indonesia's Most Valuable Treasure, Worth To Be Inscribed: Indonesia's Balinese Dance'. Culture Mag Vol.1.Jakarta : Center for Research and Development of Culture.

Jackson, R. (2014). Signposts': Policy and Practice for Teaching about Religions and Non-Religious Worldviews in Intercultural Education. Strasbourg: Council of Europe Publishing \& Lim, C., C. A.

Kumar, M., \&Nandini, N. (2013). 'Community Attitude, Perception and Willingness Towards Solid Waste Management in Bangalore City, Karnataka, India'. International Journal of Environmental Sciences Volume 4,No.1-2013, pp87-95.Code: EIJES41009. Retrived fromdoi:10.6088/ijes.2013040100009.: EJournal [6/7/2013]

Laborde, C. (2014). 'Equal Liberty, Nonestablishment and Religious Freedom'.Legal Theory20 (1), 5277.Retrived from doi : 10.1017/S1352325213000141 : E-Journal [19/3/2014]

Pradana, Gede Yoga Kharismaet. al. (2016). 'Religious Ideology Of The Tradition Of Makotek In The Era Of Globalization'.Ardhana et. al (ed).E-Journal of Cultural Studies, Volume 9 No.1, pp 6-10.ISSN 233382449. Retrived fromhttps://ojs.unud.ac.id/index.php/ecs/article/view/18425 : E-Journal [5/5/2018]

radana, Gede Yoga Kharisma et. al. (2017b). 'Local Wisdom Based Spa Tourism InUbud Village Of Bali, Indonesia'. Russian Journal of Agricultural and Socio-Economic Sciences, 8(68), pp 188-196.Retrived from.https://doi.org/10.18551/rjoas. 2017-08.22. ISSN 2226-1184. : E-Journal [5/5/2018].

Pradana, Gede Yoga Kharisma. (2017a). 'Deconstruction Powers Of Relations Behind The Shadow Puppet Performance For Tourism In Ubud Village, Bali'.Ardhana et.al (ed).Proceeding International Conference on Southeast Asian Thinkshop: Building Collaboration and Network in Globalized World. Denpasar : Postgraduate Program of Cultural Studies Faculty of Arts-Udayana Press. (Prosiding)

Pradana, Gede Yoga Kharisma et.al. (2018). "MakotekAs a Tourist Attraction In Munggu Village, Badung". Proceeding of International Conference2nd Tourism, Gastronomy and Tourist Destination.Jakarta : STP Trisakti Press.

Pradana, Gede Yoga Kharisma. (2018a). "Innovation In CenkBlonk Performance: A Strategy Of Empowering Local Language Through Balinese Shadow Puppet".Proceeding International Conference on Local Language :Empowerment and Preservation of Local Languages. Denpasar : Faculty of Arts-Udayana Press.

Pradana, Gede Yoga Kharisma. (2018b). "The Meaning Of Makotek Tradition At The Munggu Village On The Global Era".Proceeding of InternationalBali Hinduism, Tradition and Intereligious Studies Conference. Denpasar : UNHI Press.

Rahmawati, N.N.,\&Ruastiti, N.M. (2018).'The Ritual Of Bayar Saut AtTewangTampang Village, Payawan SubDistrict, Katingan District Of Central Borneo'.Rusian Journal of Agricultural and Socio-Economic Sciences.ISSN.2226-1184/Russian Federation. Registration certificate El No. FS 77-51446 of October 19, 2012/ISSUE 4(76) April 2018. Retrived fromhttps://doi org/10.18551/rjoas.2018-04/ : E-Journal [4/4/2018] 
Ruastiti, N. M. (2016). 'The Meaning of Performances of LegongRejang Dance for the Community of Selumbung Village, Karangasem Bali'.Proceeding International Conference on Southeast Asian Thinkshop: The Question of World Culture Bali Thinkshop. Denpasar: Udayana Press.

Ruastiti, N. M. (2017). 'Essence of RejangLilit Performing Art InMundeh Traditional Village, Tabanan, Bali In Global Era'. Rusian Journal of Agricultural and Socio-Economic Sciences, 5(65), pp139-147.Retrived from https://doi.org/10.18551/rjoas.2018/0301: E-Journal [5/5/2017].

Ruastiti, N. M. (2010). TransformasiSeniPertunjukan Bali MenjadiIndustriKreatif.Denpasar :Ganeca Exact.

Ruastiti, N. M. (2011). 'The Concept Of Local Genius in Balinese Performing Arts'. Journal of Mudra, Vol. 26 No.3.pp.241-245.ISSN 0854-3461.Denpasar : ISI Denpasar.

Silva, M. (2017).How Colours Matter to Philosophy. Cham : Springer. doi:10.1007/978-3-319-67398-1.

Sunarto et.al. (2014). 'Society Behavior Towards Household Waste Management in Tulungagung'. International Journal of Applied Sociology, 4(3): pp67-73. Retrived from Doi: 10.5923/j.ijas.20140403.01 : E-Journal [9/5/2018].

Suryawati P. et.al. (2018). 'Re-Actualization Of Bale BanjarFunction In Denpasar City'.Russian Journal of Agricultural and Socio-Economic Sciences.ISSN. 2226-1184/Russian Federation. Registration Certificate El No. FS 77-51446 of October 19, 2012/ISSUE 3(75) March 2018. Retrived from https://doiorg/10.18551/rjoas.2018-03.01 : E-Journal [9/5/2018].

Waweru, Rebeca. (2015). 'Factors Which Promote Community Participation in the Community Driven Development Approach'.International Journal of Humanities \& Social Science Studies (IJHSSS) Volume-I, Issue-V, Page No. 13-18.Retrieved fromhttps://www.ijhsss.com/files/RebeccaWaweru_ed86t3vk.pdf : E-Journal [9/5/2018].

Whitehouse, H., \& J.A. Lanman. (2014). 'The Ties that Bind Us : Ritual, Fusion and Identification'. Current Anthropology 55 (6), pp 674-695. Retrived from

https://www.journals.uchicago.edu/doi/abs/10.1086/678698 : E-Journal [14/10/2014]. 